\title{
Pedagogical Approaches and Design Aspects To Enable Leadership for Sustainable Development
}

\author{
Merlina Missimer, M.SLS and Tamara Connell, M.SLS
}

\begin{abstract}
Various sets of skills for dealing with sustainability and the complexity of the modern world have been put forward by different actors in the field of Education for Sustainable Development (ESD). In connection with these skills, pedagogical methods such as lifelong learning, social learning, problem-based learning, dialogue education, and empowerment for ESD have been discussed. This paper looks at how these theories and methods can be put into practice by examining a real-world example of a sustainability master's program at Blekinge Institute of Technology (BTH) in Sweden. In 2004, BTH launched the international transdisciplinary master's program Strategic Leadership towards Sustainability, which aims to develop leaders who will be able to address the ever-increasing sustainability challenge. The program combines a robust scientific framework for planning and decision making toward sustainability, with the leadership skills needed to energize large-scale societal change. In 2009, the Engineering Education for Sustainable Development (EESD) observatory awarded BTH the ranking of No. 1 in Sweden and third in Europe for demonstrating success in EESD. This paper describes the specific pedagogical approaches and design elements that were implemented to train and develop the skills and expertise surrounding leadership for sustainable development. It further presents and analyzes survey data taken from program alumni reflecting on the success of the program. The results of the survey clearly show that while there is room for improvement, overall the program design is extremely successful in equipping its graduates with the skills necessary to address the sustainability challenge. Finally, the authors offer reflections on the lessons learned after six years of continual improvements.
\end{abstract}

\section{Introduction}

The United Nations' Decade of Education for Sustainable Development (DESD) has put renewed focus on not only what we need to learn and teach in the field of sustainable development, but also how we learn and teach about sustainable development. In this context, skills that sustainability-literate individuals or leaders in the field of sustainable development should possess have been discussed as well as the best pedagogical methods for conveying these skills. This paper first reviews the skills and best-practice pedagogical methods and then turns to a case study to investigate how these methods might be implemented in order to ensure that the target groups develop the desired skills.

\section{Sustainability Leadership Skills}

The focus on employability of students upon graduation has led to a greater emphasis on outcomes-based education or competencies of students and has led to a discussion of the competencies that should be required of students graduating in the field of sustainable development. Tilbury and Cook ${ }^{1}$ discuss five key competencies for sustainability graduates; de Haan ${ }^{2}$ delineates eight, termed Gestalt competencies (German: Gestaltkompetenzen). This concept describes a set of key competencies that "enable active, reflective and co-operative participation toward sustainable development ... and are learnable but not teachable" (p. 418). ${ }^{3}$ Another set of competencies was discussed in a roundtable with practitioners in the
Education for Sustainable Development (ESD) field convened by the journal Sustainability: The Journal of Record; ${ }^{4}$ another set was put forward by the International Society for Sustainability Professionals (ISSP), based on a survey from practitioners. ${ }^{5}$ More sets have been elaborated by Svanström et al., ${ }^{6}$ Segalàs et al., ${ }^{7}$ and Thomas and Nicita. ${ }^{8}$ In a recent Blekinge Institute of Technology (BTH) master's thesis Cabeza-Erikson et al. ${ }^{9}$ specifically examine the leadership capacities for sustainability. Official organizations have also put together lists: the French national commission for UNESCO in their report on training actors for sustainable development, ${ }^{10}$ UNESCO in their review of contexts and structures for the DESD, ${ }^{11}$ and the Organisation for Economic Co-operation and Development (OECD), ${ }^{12}$

Blekinge Institute of Technology, Karlskrona, Sweden. 
Table 1. Overview of Skill Sets

\begin{tabular}{|c|c|c|c|c|c|c|c|c|c|c|c|c|}
\hline & 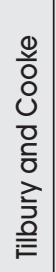 & 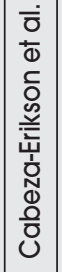 & \begin{tabular}{|c|}
$\frac{}{0}$ \\
옹 \\
응
\end{tabular} & 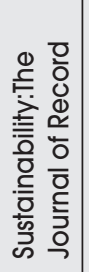 & 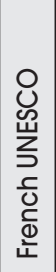 & 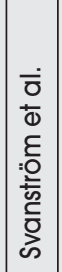 & 듬 & $\begin{array}{l}\overline{\overline{0}} \\
\overline{0} \\
\dot{0} \\
\overline{0} \\
\bar{\delta} \\
\mathbb{\infty}\end{array}$ & 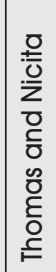 & $\begin{array}{l}\text { O } \\
\text { 岁 } \\
\text { 方 }\end{array}$ & 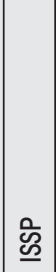 & Oे \\
\hline \multicolumn{13}{|l|}{ Ways of Thinking } \\
\hline Critical thinking & $\bullet$ & & & $\bullet$ & & $\bullet$ & $\bullet$ & $\bullet$ & $\bullet$ & $\bullet$ & & $\bullet$ \\
\hline Systems thinking & $\bullet$ & $\bullet$ & $\bullet$ & $\bullet$ & & $\bullet$ & & $\bullet$ & & $\bullet$ & $\bullet$ & $\bullet$ \\
\hline Futures-oriented thinking & $\bullet$ & & $\bullet$ & $\bullet$ & & $\bullet$ & & & & $\bullet$ & & \\
\hline Strategic thinking & & & & $\bullet$ & & & $\bullet$ & & & & $\bullet$ & \\
\hline Interdisciplinary ways of working & & & $\bullet$ & $\bullet$ & $\bullet$ & & & $\bullet$ & & $\bullet$ & & \\
\hline \multicolumn{13}{|l|}{ Working with Others } \\
\hline Inspiring a shared vision & & & & $\bullet$ & & $\bullet$ & $\bullet$ & & & & & \\
\hline Teamwork & $\bullet$ & & - & & $\bullet$ & $\bullet$ & $\bullet$ & $\bullet$ & $\bullet$ & & & $\bullet$ \\
\hline $\begin{array}{l}\text { Working in multicultural } \\
\text { (diverse) settings }\end{array}$ & $\bullet$ & & - & & - & • & & $\bullet$ & • & • & & • \\
\hline Networking, building alliances & & & & $\bullet$ & & & $\bullet$ & & & & & \\
\hline Participatory skills, decision making & & & & & & $\bullet$ & $\bullet$ & $\bullet$ & & $\bullet$ & & $\bullet$ \\
\hline $\begin{array}{l}\text { Conflict resolution skills/consensus } \\
\text { building }\end{array}$ & & & $\bullet$ & & & $\bullet$ & & $\bullet$ & & $\bullet$ & & \\
\hline Communication skills & & $\bullet$ & & $\bullet$ & & $\bullet$ & $\bullet$ & $\bullet$ & $\bullet$ & & $\bullet$ & $\bullet$ \\
\hline $\begin{array}{l}\text { Focusing on process, dialogue, } \\
\text { listening }\end{array}$ & & $\bullet$ & & & & $\bullet$ & $\bullet$ & $\bullet$ & & & & $\bullet$ \\
\hline $\begin{array}{l}\text { Enabling/Motivating others to } \\
\text { act/participate }\end{array}$ & $\bullet$ & & $\bullet$ & • & $\bullet$ & $\bullet$ & - & & & & - & $\bullet$ \\
\hline Catalyzing/managing change & $\bullet$ & & $\bullet$ & $\bullet$ & & $\bullet$ & & & & $\bullet$ & & \\
\hline \multicolumn{13}{|l|}{ Personal Skills } \\
\hline $\begin{array}{l}\text { Ability to reflect/self-evaluate } \\
\text { (alone and in a group) }\end{array}$ & & & $\bullet, 1$ & & $\bullet$ & $\bullet$ & $\bullet$ & & & $\bullet$ & & \\
\hline $\begin{array}{l}\text { Capacity for empathy, compassion, } \\
\text { solidarity }\end{array}$ & & $\bullet, 3$ & $\bullet, 3$ & & & $\bullet$ & & $\bullet$ & & $\bullet$ & & \\
\hline Ability to constantly renew energy & & $\bullet$ & & & & $\bullet, 2$ & & & & & & \\
\hline $\begin{array}{l}\text { Dealing with complexity and } \\
\text { uncertainty }\end{array}$ & $\bullet$ & & & $\bullet, 4$ & & $\bullet$ & $\bullet$ & $\bullet$ & & & & \\
\hline $\begin{array}{l}\text { Practical problem-solving/ } \\
\text { management/planning skills }\end{array}$ & $\bullet$ & & $\bullet$ & $\bullet$ & & $\bullet$ & $\bullet$ & $\bullet$ & $\bullet$ & $\bullet$ & $\bullet$ & $\bullet$ \\
\hline Commitment to learn/develop & & $\bullet$ & & $\bullet$ & & & & $\bullet$ & & & & \\
\hline Creativity & & & & $\bullet$ & & $\bullet$ & $\bullet$ & & $\bullet$ & & & \\
\hline Inspiration/hope/can-do attitude & & & & & & $\bullet$ & • & & & & • & \\
\hline
\end{tabular}

1) The concept of Gestalt competencies specifies the need for reflection on individual and cultural mental models.

2) Svanström et al. list the ability to be resilient.

3) Cabeza-Erikson et al. and Svanström et al. list emotional intelligence specifically.

4) Sustainability: The Journal of Record lists the ability to improvise, adapt, and improve. whose slightly broader list is proposed as skills for the 21 st century. The comprehensive Egan review for the U.K. government discusses in depth which skills and competencies are needed to move sustainable communities forward. ${ }^{13}$ Most of these sets highlight critical, strategic, analytical, and systematic thinking abilities as well as several competencies for working in diverse teams and additional personal skills such as the ability to reflect, or deal with complexity. One report by Meehan and Thomas ${ }^{14}$ focuses specifically on the ability to work in teams. Table 1 gives an overview of the competencies and will be used later as the basis for discussion.

It is clear that the categories are in many ways overlapping and that, of course, there are nuances, which are emphasized differently by different actors. For example, Thomas and Nicita, ${ }^{8}$ Egan, ${ }^{13}$ and the OECD ${ }^{12}$ all mention leadership skills, but do not elaborate what this would entail. Similarly, Thomas and Nicita $^{8}$ mention interpersonal skills, which could cover many of the skills listed in Table 1 , but was not indicated as such because it seemed too vague. In addition, UNESCO also mentioned the ability to clarify one's own values and to deal with crisis and risk; ${ }^{11}$ Svanström et al. named challenging the process appropriately; ${ }^{6}$ Thomas and Nicita ${ }^{8}$ listed the ability to work independently (as well as in teams) and the roundtable, ${ }^{4}$ among others, discussed the ability to deal well with finances on a more practical level. Overall, the ISSP $^{5}$ concluded that, based on their survey results, soft skills such as communication ability and motivating others were more important than so-called hard skills like strategic thinking.

\section{Pedagogical Approaches to Sustainable Development}

In addition to the what of ESD, the pedagogies of how to teach and learn in the field of sustainable development have gained increasing attention. The Barcelona Declaration on Engineering Education in Sustainable Development calls for a review of teaching and learning techniques. ${ }^{15}$ Similarly, a conference on the focus of the research agenda for Sustainable Development $(\mathrm{SD})$ ranked the impact of teaching and learning methods as the highest priority. ${ }^{16}$ There is also a large debate in the field as to whether a complete transformation of the education sector is necessary in order for ESD to be successful. ${ }^{17-20}$ The following 
section reviews the pedagogical approaches discussed in the field.

Lifelong Learning has been intensively discussed in the official UNESCO strategy for the DESD $11,{ }^{21-22}$ and in engineering education. ${ }^{23-24}$ The concept of lifelong learning states that learning is not confined to official education in the younger years, but that learning takes place, and should take place, at all ages in all different situations (formal, informal, and nonformal). According to the European Union, in order to facilitate this approach, there needs to be a focus on learning to learn, which is also anchored in the Bologna Process. ${ }^{25-26}$

Social Learning (sometimes referred to as collaborative learning), another pedagogical concept often discussed in connection with ESD, ${ }^{27-36}$ focuses on the idea that we learn best in interactions with others when we learn with and through them. ${ }^{37-38}$ Lipman $^{39}$ claims that democratic and collaborative "communities of enquiry" best facilitate this learning. Luksa and Siebenhünerb ${ }^{40}$ add that this approach requires interaction of diverse groups and stakeholders. In the context of ESD, social learning has been described as the most appropriate and even necessary process. ${ }^{41-43}$ There are several reasons for this. When people learn together, the collective knowledge and skills are far greater than what can be achieved by an individual. Mastery of SD clearly needs large amounts of knowledge and competencies and therefore collective learning efforts seem the most efficient. Additionally, reflective and critical thinking are essential competencies for sustainability practitioners and they are best trained in situations in which there are multiple viewpoints and assumptions are challenged. Finally, new world views, like the ones needed for sustainable development, are more easily formed in this setting. ${ }^{44-45}$

Problem-Based Learning (PBL) is another approach that has been widely discussed in the literature. ${ }^{46-52} \mathrm{PBL}$ is based on the idea that learning occurs when students are given real-life, complex problems. Since real problems help students put their learning into practice and see its relevance, the method can result in higher student engagement and also better learning. ${ }^{50,}$,53-54 The approach tends to be particularly effective when applied in teams of learners ${ }^{55-56}$ and also resembles the real world more closely since sustainable development work often requires transdisciplinary teams and the cross-fertilization of knowledge. ${ }^{57-59} \mathrm{PBL}$ is often connected to social learning as it "promotes the idea that nothing is ever learned to finality, that there exists too much for any one person to learn, and that tasks need to be shared among students" (p. 161).52

Active and Experiential Learning is also featured in the literature ${ }^{55,60-65}$ with a focus on the responsibility of the learner for his/her own learning, and as the term suggests, on the active participation of the learner. Calder and Clugston claim that this approach enhances the development of the critical thinking skills necessary for addressing issues of sustainability. ${ }^{66}$ De Graaff et al. discuss active learning as a means to address the learning to learn aspect of lifelong learning. ${ }^{24}$ Similarly, experiential learning describes the approach of learning by doing. Many argue that this method provides a richer educational experience than a traditional lecture-style approach because students become more personally involved and learning becomes a discovery process, ${ }^{67-68}$ specifically for ESD. ${ }^{18,69}$

Transformative or Transformational Learning is another term often used in connection with $\mathrm{ESD},{ }^{6,70-73}$ but there does not seem to be much literature on how this approach has been concretely incorporated into course design. ${ }^{72}$ Transformative learning means "becoming critically aware of one's own tacit assumptions and expectations and those of others and assessing their relevance for making an interpretation" (p. $4)^{74}$ as the highest level of learning, rather than just remembering information or being able to critically analyze it.

Empowerment, understood as enabling someone to act, is also often discussed in the ESD literature. ${ }^{75-79}$ Stapp ${ }^{80}$ asks: "How do we develop curricula and instructional strategies that emphasize the global component of local environmental issues, but do not overwhelm students or cause them to lose hope? How can we educate and empower students to take action on local issues while simultaneously developing within them an international cross-cultural perspective? How can we best encourage this first generation of truly planetary citizens to assume responsibility for their shared home?" (p. 184). Holden et al. ${ }^{81}$ discuss the empowerment of students in the classroom specifically through the use of some of above-mentioned pedagogies in a course on green building. Stapp ${ }^{80}$ asserts that "carefully guided and properly focused, the problem-solving and action-taking components can be an empowering experience for both teachers and students" (p. 190). Evitts et al., based on their interviews, discuss the need for a positive approach and empowerment of learners. The overwhelming nature of sustainability work makes it essential that the learning is always linked to action and conveys the feeling that the learner can do something about the situation. ${ }^{20}$

Dialogue Education is specifically designed for adult learning. Vella ${ }^{82}$ outlines 15 principles based on the idea that adults have enough life experience to be in dialogue with anyone and will learn best in relation to that life experience. Some of Vella's principles are: safety/safe spaces for the learner, conducting an assessment of the actual learning needs of the students, incorporating different learning styles, the need of relevancy for the learner, and the importance of team work. Dialogue education is specifically used by the Natural Step organization in their workshop design.

\section{Constructivist Approaches and Student-Centered Learning}

Loeber et al. sum up ${ }^{83}$ that ESD is best achieved through "action-oriented processes of learning that take place in regular societal contexts rather than in formal educational settings" (p. 85). Segalàs et al..$^{84}$ come to a similar conclusion; their study shows that students achieve better cognitive learning results and acquire a broader knowledge in the realm of SD when more communityoriented, active, and constructive-learning pedagogical approaches are applied. The theory of constructivist education explains that learning is a process of construction of and confrontation with meaning, and that this meaning construction occurs in a social context. Biggs and Tang ${ }^{85}$ state: "Learners construct knowledge with their own activities, building on what they already know. Teaching is not a matter of transmitting, but of engaging students in active learning, building their knowledge in terms of what they already understand" (p. 21). In this vein, the above-mentioned approaches share the main idea that students learn based on their own context and that in order to be interested in the learning, the content needs to be relevant and meaningful to them (either because it is connected to their prior experience or will be needed in their immediate future). ESD is therefore an 
inherently student-centered process in which the instructor's role is that of a facilitator, coach, or guide. ${ }^{86-89}$ Literature on transformative learning for sustainability especially emphasizes that teachers need to have gone through a process of transformation themselves, ${ }^{20}$ that they should use dialogic methods for teaching and design learning processes that allow for selfunderstanding and empowerment of the student, ${ }^{74}$ and that above all "those who teach consider themselves learners as well" (p. 49). ${ }^{70}$ According to Wals and Blaze Corcoran, ${ }^{71}$ "Education for sustainability, above all, means the creation of space for transformative social learning" (p. 107). Terry Link in the roundtable convened by Sustainability: The Journal of Record sums up the situation aptly: ${ }^{4}$

I don't mean this in any disrespect, but I don't think any of us know what the heck we're doing. That's a good, honest first place to begin, because what we need is a transformation, not a tinkering around the edges, but a total transformation of how we organize ourselves to accomplish what it is we want to accomplish in the world. When we can create the environments that nurture the space for many others to come together, then we're moving in a direction that we have to go in. Otherwise ... I think we end up defending turf spots as opposed to opening up the creative possibilities that are out there (p. 235).

Having discussed the skills needed for sustainability leadership and the pedagogical approaches that might facilitate them, this paper now examines a case study, the master's in Strategic Leadership towards Sustainability program, to look at how these ideas are implemented in the realities of an accredited master's-level educational program.

\section{The Strategic Leadership toward Sustainability (MSLS) Program (Case Study)}

Since the 1990s, BTH has integrated sustainability aspects into all engineering degrees. In 2004 it launched the international transdisciplinary master's in Strategic Leadership towards Sustainability (MSLS) program (see also Waldron and Leung $\left.{ }^{90}\right)$. Each year the program welcomes approximately 60 students, who in total have represented more than 50 countries. The program aims to attract early- to midcareer professionals, and has welcomed participants from ages 22 to 61 from a vast array of personal and professional backgrounds. This 10 -month program aims to develop leaders who will be able to address the ever-increasing sustainability challenge. It combines a robust scientific framework for planning and decision making toward sustainability (known as the Framework for Strategic Sustainable Development, or the Natural Step Framework), with the personal and organizational leadership skills needed to energize large-scale societal change. As of June 2012, the program will have graduated eight cohorts, totaling more than 400 students.

\section{Method}

The MSLS program is used as a case study in two ways. Using the best-practice pedagogical approaches presented above, the authors analyzed if and how the specific pedagogical approaches have been incorporated into the design of the MSLS program. Discussion with past and present MSLS program staff helped the authors to ensure a thorough analysis. Secondly, MSLS program alumni were surveyed to discern to what degree the aforementioned sustainability leadership skills successfully evolved during their participation in the MSLS program, and where possible, which specific design elements contributed to the overall success or impact of the program. The survey was conducted using online survey software (Survey Monkey Pro) and attempts were made to contact all alumni from all past years using e-mail, group listserves, word of mouth, and other MSLS-specific social media platforms. Results were compiled directly via the online survey platform, which allowed the authors to check responses, validate directly with the individuals where in question, and then summarize the findings.

\section{Results}

The results section explores the key findings in the following order. First, the MSLS program is described, showing how many of the best-practice pedagogical approaches have been incorporated. Where appropriate, quotations from the alumni survey are used as a supplement when their comments were linked directly to the pedagogical approaches. Following that, a summary of the results of the MSLS program alumni survey is presented, which reveals to what degree the sustainability leadership skills were actually strengthened. Thus, the results section follows the sequence of design and then output, to attempt to show a correlation between intent and achieved goals.

\section{Pedagogical Approaches of the MSLS program}

Overview. While the authors of this paper agree with much of the literature that argues for a paradigm shift in the way that we teach and learn regarding ESD, they also believe that much can be achieved within the current academic and pedagogical system. The MSLS program can be viewed as an example of this. As previously mentioned, the program focuses on two themes. The first is a planning and decision-making framework for moving toward sustainability, known as the Framework for Strategic Sustainable Development (FSSD). The second theme is organizational learning and changeinquiring into how to use both personal and collective leadership to help energize change.

The MSLS program is structured around a model of five learning loops or circles; as the program progresses, students "circle" around a set of core aspects, each time gaining increasing depth and complexity. The Swedish educational system includes four learning periods, each approximately two months long. In period 1 (learning circles 1-3), all students take the course Introduction to Strategic Leadership towards Sustainability (15 credits). In period 2 (learning circle 4), all students take the course Strategic Management for Sustainability $(7.5$ credits) and choose either Advanced Societal Leadership or Engineering for a Sustainable Society (each of these electives is 7.5 credits). Finally, periods 3 and 4 (learning circle 5) are allocated to a thesis project, conducted in small groups of 3 or 4 students each.

The role of staff shifts in a conscious and explicit manner, from teaching, i.e., providing information in period 1 , to coaching, i.e., allowing the students to apply the information while giving explicit guidance or correction as needed in period 2 , to advising, i.e., allowing the students to take the lead on seeking out new information and cases to apply their core knowledge in periods 3 and 4 (see Figure 1). 


\section{Two themes, integrated through five learning circles}

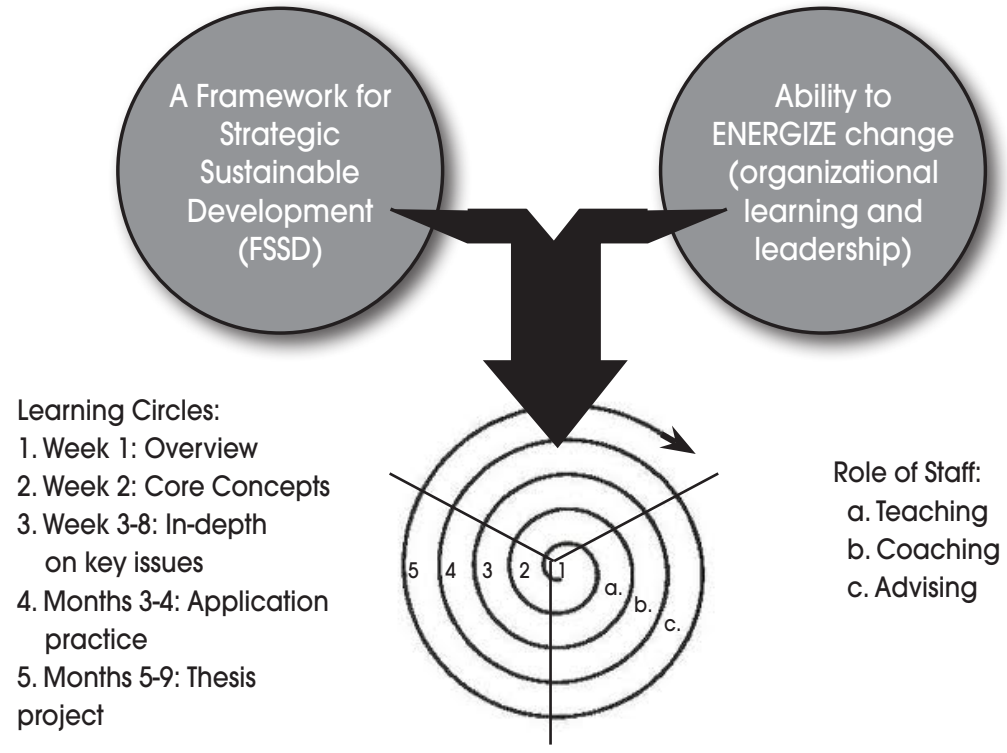

Figure 1. Overall MSLS approach

Starting in 2007, a personal leadership thread was incorporated into the program design. This leadership thread is aimed at providing additional personal skills, such as giving and receiving feedback, active and deep listening, and presentation skills, among others. While not officially its own course, the leadership thread sessions are clearly articulated as such to the students-distinguished from other course sessions-and in line with the overall approach of the staff, students are encouraged to take more of a lead to develop and/or arrange their desired sessions as the academic year progresses.

At the time of writing, the entire core staff team (program director, course leads, and program assistants) are all MSLS program alumni. Content experts are brought in to hold lectures and facilitate workshops, primarily during periods 1 and 2 where the sharing of knowledge and experience is most appropriate. The program advertises and strives for a nontraditional learning environment with self-directed learning, co-learning, and co-creation explicitly emphasized. As an example, the first day and a half of the program is built around an Open Space session where students self-organize to discuss and report on how they will work together and what their aims are for the subsequent 10 months. The vast majority of the assignments, including the final thesis project, are conducted in teams.
During the introduction session to the program (day 1), the key learning and teaching approaches are shared, including the two themes, the learning circles, the role of the staff, and the invitation to co-create the year ahead. The staff articulate early on that the year will include a large degree of peer learning, and in fact, that the staff will often be learning from the students. This is later repeated to the students at various points throughout the program. Transparency and openness are considered core values of the program team.

An aspect deemed critical by the program staff, but not necessarily communicated explicitly to the students is the focus on creating a safe space. This means that mistakes are viewed as learning opportunities, appreciative inquiry is used, and open and honest feedback is given with a view to helping others to achieve their greatest potential. The staff aim to lead by example at all times, demonstrating care, compassion, and openness. Additionally, the staff members are encouraged to host and attend social events, creating a degree of camaraderie with the students.

Assignments and exams are constructed in a manner that requires the application rather than memorization of core knowledge. Both also incorporate the explicit task of reflection, both personally and within the group, using debriefs of lessons learned, feedback to their peers, and even self-grading against their own learning objectives. (See also Waldron and Leung ${ }^{90}$ for a discussion of the MSLS program and its design within the years 2004-2008.)

Application of pedagogical theories. This section examines the MSLS program in relation to the pedagogical theories previously referenced. It is constructed from assessments by the authors and other current and former staff members. Although pedagogical approaches were not extensively surveyed from the MSLS program alumni, some comments are included here when they clearly link to specific methods and provide supplementary information.

Lifelong learning is implicit in many ways, not the least of which is that the learning circles (see Figure 1) continue even after the program is officially over; learners are never given the impression that they will learn all of either of the two themes while being at the master's program. Continual learning and progressively drilling deeper into areas of interest is a tenet of the overall approach of the program. When choosing assignment topics, students are encouraged to seek out areas in which they would like to deepen their knowledge. As a program aiming to instill a transdisciplinary way of thinking in the students, the intent is to provide a manner of synthesis of ideas, often gained from others (persons or disciplines, or both). One respondent in the survey noted: "I found the program focus to be more on synthesizing (putting together) than analyzing (picking apart). That's a good thing!" Another reflected: "Since the challenges, tools, concepts and approaches in SD are continually changing, I can't ever say that I know a sufficient amount of information. We'll always be learning. I can say that I have a strong enough base that I'm comfortable with what I don't know, and find that I'm able to ask good questions, and have good conversations with people to learn about new approaches/tools/concepts, etc., which is indispensable in this field."

One could argue furthermore, that from a constructivist/student-centered approach, the ability to synthesize ideas, reflect on them, and apply them in new ways is the highest form of learning, often resulting in transformational learning. Another survey respondent summarized the transformational and lifelong learning (as well as social learning) approaches nicely: "Circumstances in which we study at MSLS put us 
in a situation where we, the class, build the community from scratch-planting seeds of our dreams and desires of a desired community we all would like to be part of. MSLS is more than formal education-it is a way of living, it is a community of committed people, it is a possibility to practice living your dream, so when you leave MSLS you would repeat the case again, and again, and again! Thank you for the incredible experience!"

Social learning (collaborative learning) is key ingredient in the program. As described earlier, nearly every assignment is conducted in groups, beginning with a group Open Space assignment on day 1, through to the completion of a group thesis project in the final periods. Not only do these assignments facilitate social learning, but they are also designed to incorporate problem-based learning. For example, in the mandatory class Strategic Management for Sustainability, student groups work directly with a real organization of their choice to assess and make recommendations for the organization's future steps toward sustainability. Students use each others' strengths and backgrounds to build solid recommendations to begin to solve the problem of the sustainability challenge for these organizations.

Projects such as these also display characteristics of active/experiential learning, by working directly with an organization to solve its challenges, and empowerment, by having the opportunity to choose organizations and attempt to apply theory to practice while being coached and guided by others. When looking at the survey results, it stood out to the authors that the students thought both social learning and problembased learning were especially important to the overall success of the program: $47 \%$ ranked social learning as a "Very Positive" aspect of program, $43 \%$ ranked it as "Critical/Essential." ${ }^{11}$ For problem-based learning $40 \%$ deemed it to be "Very Positive," and a further $40 \%$ deemed it "Critical/Essential." One commenter, responding to the capacities learned, added the suggestion "being a contributor to a movement and network (not just a passenger)."

Dialogue and dialogue education are present both implicitly and explicitly within the program design. By the very nature of group assignments, dialogue is a key requirement to arrive at a successful group product. The program also incorporates two separate Dialogue Café sessions throughout the year, in addition to the day-and-half Open Space session at the program kickoff, allowing the students to engage in dialogue, set common goals, identify their learning needs, and work together to build solutions. Furthermore, in certain courses and assignments, such as the Advanced Societal Leadership course, students are invited to set their own learning goals for the course, and then assess their own performance as a small portion of their final course grade. This allows the students to take control of their own learning (which is also an important aspect of lifelong learning, transformative learning, and empowerment) and then practice reflecting on their own achievements. Additionally, many of the group assignments incorporate peer evaluation and/or feedback as well as group debrief sessions after the projects are completed. When asked about the impact of specific design elements, respondents appeared to strongly support the pedagogical design connected to transdisciplinarity and diversity of opinions, with $92 \%$ of students selecting either "Very Positive" or "Critical/Essential" for "group projects" and $94 \%$ selecting those categories for "diversity of MSLS participants."

Based on the results, the authors feel confident that all pedagogical theories are addressed in some way (often in many different ways) throughout the MSLS program. As a way to determine if the design actually leads to creating the appropriate space for individual skill enhancement, the authors undertook an alumni survey, specifically related to the sustainability leadership skills outlined in the introduction. The results follow.

\section{Alumni Survey Results}

Of the 306 program participants (alumni), ${ }^{92}$ 142 online surveys were entered, of which 128 (90\%) were deemed completed. There was a good sampling from all classes; the response rate varied from 16 responses from the graduating classes of 2005 and 2007, up to 40 responses from 2010.

The survey asked: "Did your participation in the MSLS program enhance or develop these ways of thinking?" In the results, almost all Ways of Thinking listed in Table 1 were reported to have been positively enhanced, ${ }^{93}$ showing results of $94-97 \%$ each. Only "Critical Thinking" stood out at slightly lower in impact (total of $81 \%$ positive impact), where many students (24\%) deemed that they "Were already quite good at this, and there- fore there was little room for improvement"; $39 \%$ deemed that this skill was "Somewhat enhanced" and a further 23\% deemed it was "Greatly enhanced." One respondent made an interesting point: "The greatest improvement to me was to be able to take all of these ways of thinking and put them together all at once over a specific challenge without becoming totally overwhelmed."

Related to skills connected to working with others, positive impact was identified by a high majority (more than three-quarters of respondents). The most strongly enhanced were "Ability to inspire or create a shared vision with others" (combined positive impact of 93\%), the "Ability to work in diverse groups" (92\%) and "Ability to attend to the group/team processes" (90\%). The least enhanced was the "Ability to resolve conflicts" (76\% positive impact) and "Ability to motivate others to act or participate" (79\% positive impact). One alumnus noted, the "biggest learning for me was that collaboration is needed in a world where we strategically move closer towards sustainability even in circumstances of competition and yet it is most likely one of our biggest challenges."

When considering personal skills, the vast majority of these skills were reportedly enhanced for $79-89 \%$ of the respondents. The most obvious outlier was related to "Ability to find ways to renew one's energy," which was deemed by only $59 \%$ to be positively impacted (41\% "Not enhanced"). The highest positive impacts of participation in the MSLS program were seen in the categories of "Ability to reflect on group processes" (89\%), "Ability to deal with complexity and uncertainty in an effective manner" (88\%), "Ability to solve problems, manage projects, and carry out plans" (87\%) followed by "Ability to empathize, develop compassion, and/or show solidarity with others" (84\%), "Ability to reflect on your own performance, behavior, reactions, etc. (e.g., via self-evaluation)" (83\%), and "Ability to find hope and/or maintain personal motivation and inspiration" (78\%). "I did really enjoy the optimistic, change-is-possible, inspirational aspects of the program. With a background in political science and environmental studies, the doom and gloom of my prior education-the program was a breath of fresh air in that regard," said one graduate. Another stated, "One of the main things I took away from MSLS was that there are many, many wonderful and motivated people who care 
for humanity and the planet, which helped to decrease any doom-and-gloom mentality that I had periodically experienced before."

The authors assessed other skills, not specific to ESD, but rather to general employability. The most highly reported enhanced skills were "Formal and informal presentation skills" (speaking in front of others; 92\%), and "Facilitation skills" (ability to run/ guide/host/moderate meetings, workshops, or other group sessions; 90\%). Employment after graduation was also surveyed, indicating that at least half of the respondents were able to find meaningful work within six months of graduation. ${ }^{94}$ Two-thirds of the respondents reported that participation in the program allowed them to change industries, fields, jobs, or roles in a way that was good for their professional development, and three-quarters of the respondents reported that their current employment was relevant or related to what they studied within the MSLS program.

When asked about their overall experience within the MSLS program, 2\% stated that is was "Neutral," 23\% stated that it was "Good," and $75 \%$ rated it "Excellent." Words to describe the program were "incredible," "most meaningful year of my life," and "has a magical element to it that a survey or words just can't describe." Table 2 gives more results related to overall impact.

\section{Discussion and Conclusions}

The results of this study seem to indicate that it is indeed possible to incorporate all the various recommended pedagogical approaches/theories found in the literature within an accredited program, while adhering to many of the common requirements of today's academic institutions. This study also seems to indicate that the alumni of the Strategic Leadership towards Sustainability program have had positive experiences, enabling them to build a variety of key skills. What is most promising of the results shown is that it appears that the content, context, and setting provided by the MSLS program help to facilitate the development of whole individuals, with not only knowledge, but also the skills, confidence, and support network that can lead them to be professionally well-equipped in the quest to build a more sustainable society.

It is the opinion of the authors that, by its very nature, any program designed around

\begin{tabular}{|c|c|c|c|c|c|c|}
\hline $\begin{array}{l}\text { To what degree do you feel your } \\
\text { participation in the MSLS program } \\
\text { enhanced your ... }\end{array}$ & 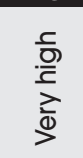 & 음 & 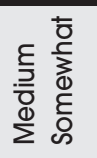 & 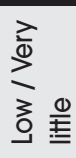 & $\begin{array}{l}\overline{\overline{0}} \\
\bar{t} \\
\bar{t} \\
\bar{c}\end{array}$ & 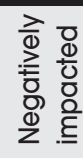 \\
\hline $\begin{array}{l}\text { Ability to find desirable/meaningful } \\
\text { work (employment, volunteer, or } \\
\text { other professional engagement) }\end{array}$ & $\begin{array}{c}37.8 \% \\
(45)\end{array}$ & $\begin{array}{c}24.4 \% \\
(29)\end{array}$ & $\begin{array}{c}28.6 \% \\
(34)\end{array}$ & $\begin{array}{c}5.9 \% \\
(7)\end{array}$ & $\begin{array}{c}2.5 \% \\
(3)\end{array}$ & $\begin{array}{c}0.8 \% \\
(1)\end{array}$ \\
\hline $\begin{array}{l}\text { Personal development/growth, } \\
\text { or direction }\end{array}$ & $\begin{array}{c}59.8 \% \\
(76)\end{array}$ & $\begin{array}{c}31.5 \% \\
(40)\end{array}$ & $\begin{array}{l}7.9 \% \\
(10)\end{array}$ & $\begin{array}{c}0.8 \% \\
(1)\end{array}$ & $\begin{array}{l}0.0 \% \\
(0)\end{array}$ & $\begin{array}{l}0.0 \% \\
(0)\end{array}$ \\
\hline $\begin{array}{l}\text { Knowledge about sustainability/ } \\
\text { sustainabledevelopment, and some } \\
\text { concepts/actions/tools related to it }\end{array}$ & $\begin{array}{l}65.1 \% \\
(82)\end{array}$ & $\begin{array}{c}30.2 \% \\
(38)\end{array}$ & $\begin{array}{l}4.8 \% \\
(6)\end{array}$ & $\begin{array}{c}0.0 \% \\
(0)\end{array}$ & $\begin{array}{c}0.0 \% \\
(0)\end{array}$ & $\begin{array}{c}0.0 \% \\
(0)\end{array}$ \\
\hline Social and/or support network & $\begin{array}{c}43.3 \% \\
(55)\end{array}$ & $\begin{array}{c}29.9 \% \\
(38)\end{array}$ & $\begin{array}{c}22.0 \% \\
(28)\end{array}$ & $\begin{array}{c}3.9 \% \\
(5)\end{array}$ & $\begin{array}{l}0.0 \% \\
(0)\end{array}$ & $\begin{array}{c}0.8 \% \\
(1)\end{array}$ \\
\hline
\end{tabular}

sustainable development is likely to have an element of problem-based learning, active/experiential learning, and perhaps even transformative learning, as ESD invites learners to solve the largest problem of our current time-the sustainability challengeand often by changing mental models/paradigms in terms of how we view the world and our places within it. One key element, which the authors feel sets the MSLS program apart from other programs related to $\mathrm{SD}$, is the pairing of the two themes: the Framework for Strategic Sustainable Development and the Organizational Learning and Leadership component. Without the second of the two themes, the focus on creating a true learning organization (or perhaps several integrated and interdependent learning organizations-the group of students, the program staff, and the alumni) where all participants are consciously invited to co-create something meaningful, may not have led to such student-centeredness, and thus would not likely have incorporated many of the bestpractice pedagogical approaches. By continuing to engage with the original program founders, designers, and managers, the current program team has been able to hold firmly to the key element of organizational learning while still adjusting and enhancing the program according to emerging trends, data, and case studies. Beyond this, the mere fact that the MSLS program is a competitiveentry single-year master's degree means that the participants are typically extremely passionate, motivated, and enthusiastic about embarking on new ways of learning and sharing with others.

In terms of the alumni input, there seemed to be a high level of agreement that the students were able to build many of the sus- tainability leadership skills suggested in the literature. The largest areas still left for improvement seemed to be in relation to helping the students to solve conflict, maintain personal balance, and have enough space to reflect and digest all the teachings. Respondents stated, "For me, I found there wasn't enough time, headspace, or the resources needed to really support this for myself," and, "My only criticism is that the program tried to do too much in too short a time." These comments are particularly important for current and future staff to keep in mind; with so much information and attention growing around the sustainability challenge, it is oftentimes hard not to take on too much.

The MSLS program staff remains very focused on creating a safe space and encouraging the students to take the lead on many aspects of the program as well as their own learning. Simultaneously the program staff focuses on practicing and displaying the characteristics of a learning organization-continually discussing, reflecting, and updating both content and pedagogy. One respondent, when commenting on how his/her participation in the MSLS program enhanced personal skills/capacities stated, "These things are more about the space provided by the program rather than specific content." When attempting to analyze which specific design elements might contribute to the overall success of the program, it can be difficult to articulate and measure individual elements; something special often happens during 10 months of attendance at the MSLS program, but it is challenging to pinpoint exactly which pedagogical approach or specific design element contributes in a particular way. One potential ingredient is that

\section{Sustainability}


having a young staff, currently all program alumni, might allow for the complete integration of a student-centered approach. The potential downside of this staffing approach is that there has been continual turnover of program assistants, which can bring additional administrative strain.

Finally, it is essential to reflect on the fact that the MSLS program is hosted by BTH, a young and progressive school. By having the backing and support of BTH for the staff to explore nontraditional ways of working and engaging in learning, this program has been able to truly experiment, push the boundaries, and arrive at an educational offering that garners praise from others, most notably the students who have passed through its doors. A comment from the survey summarizes: "This program is exactly the opposite of how education is structured in the U.S. In the U.S., we take engineering, M.B.A., law, policy and infuse it with sustainability, but in the end you get an engineering, law, or business degree. The MSLS program teaches you sustainability and weaves in engineering, leadership, and business management, so you truly get a sustainability degree."

This paper has attempted to shed light on how this particular case study, the MSLS program, incorporated best-practice pedagogical approaches in an effort to develop skilled graduates capable of leading within the field of sustainable development. It is the hope and desire of the authors that others might be able to take inspiration and ideas from this and apply it within their own contexts.

\section{Author Disclosure Statement}

No conflicting financial interests exist.

\section{References}

1. Tilbury D, and Cooke K. Building capacity for a sustainable future. Macquarie University, Sydney. 2001

2. de Haan G. The BLK ' 21 ' program in Germany: A 'Gestaltungskompetenz'-based model for Education for Sustainable Development. Environ Educ 2006;12(1):19-33.

3. Barth M, Godemann J, Rieckmann M, et al. Developing key competencies for sustainable development in higher education. Int J Sustain in Higher Educ 2007;8(4):416-430.

4. Sustainability: The Journal of Record. Core competencies for sustainability professionals: What educational background and job skills do they really need? Sustain J Re- cord 2008;1(4):233-238.

5. Willard M, Wiedmeyer C, Flint RW, et al. The Sustainability Professional: 2010 Competency Survey Report. International Society of Sustainability Practitioners, Portland, Oregon, 2010. http://sustainabilityprofessionals.org/sustainability-professional2010-competency-survey-report (last accessed 7/9/2010).

6. Svanström M, Lozano-Garcia F, and Rowe D. Learning outcomes for sustainable development in higher education. Int J Sustain in Higher Educ 2003;9(3):339-351.

7. Segalàs J, Ferrer-Balas D, Svanström M, et al. What has to be learnt for sustainability? A comparison of bachelor engineering education competences at three European universities. Sustain Sci 2009;4:17-27.

8. Thomas I, and Nicita J. Employers' expectations of graduates of environmental courses: An Australian experience. Appl Environ Educ Commun 2003;2:49-59.

9. Cabeza-Erikson I, Edwards K, and van Brabant T. Development of leadership capacities as a strategic factor for sustainability. Master's thesis, Blekinge Institute of Technology, Karlskrona, Sweden, 2008. http://bth.se/ste/tmslm.nsf/pages/21165b8 b1149400fc125721f0051efe4!OpenDocume nt (last accessed 7/9/2010).

10. French National Commission for UNESCO. Training of Actors for Sustainable Development-Challenges Faced by the Sustainable Development Pole of UNESCO Chairs in France. International Institute for Educational Planning, Paris, 2009. http:// chaire-unesco-dait.org/wp-content/uploads/susdev_eng-version-publiee-pdf.pdf (last accessed 7/9/2010).

11. United Nations Educational, Scientific and Cultural Organization (UNESCO). United Nations Decade of Education for Sustainable Development (DESD, 20052014): Review of Contexts and Structures for Education for Sustainable Development. Section for Education for Sustainable Development (ED/PEQ/ESD), Division for the Promotion of Quality Education, UNESCO, Paris, 2009. http://www.unesco.org/en/esd/ publications/ (last accessed 7/9/2010).

12. Organisation for Economic Co-operation and Development (OECD). Education Policy Analysis 2001-Competencies for the Knowledge Economy, 2001. http://www. oecd.org/ dataoecd/42/25/1842070.pdf (last accessed 7/2/2010).

13. Egan J. Skills for Sustainable Communities. Office of the Deputy Prime Minister, London, 2004. http://www.communities. gov.uk/publications/communities/eganreview (last accessed 7/2/2010)

14. Meehan B, and Thomas I. Team work: Education for entrants to the environment professions. Environ Educ Res 2006;12(5):609-623.

15. Barcelona Declaration. Engineering Education in Sustainable Development Conference, 2004. Barcelona, Spain. http://eesd08. tugraz.at/pics/declaration_of_barcelona_ english.pdf (last accessed 7/9/2010).

16. Wright T. Higher education for sustainability: Developing a comprehensive research agenda. J Educ Sustain Dev 2007;1(1):101-106.

17. Sterling S. Sustainable Education: Re-visioning Learning and Change. Green Books, Totnes, England, 2001.

18. Jucker R. Our Common Illiteracy: Education As If the Earth and People Mattered. Peter Laing, Frankfurt, , 2002.

19. Wals AEJ, and Corcoran PB. Sustainability as an Outcome of Transformative Learning. Drivers and Barriers for Implementing Sustainable Development in Higher Education. Education for Sustainable Development in Action, Technical Paper 3, UNESCO, 2005.

20. Evitts S, Seale B, and Skybrook D. Developing an interconnected worldview: A guiding process for learning. Master's thesis, Blekinge Institute of Technology, Karlskrona, Sweden, 2010. http://bth.se/ste/ tmslm.nsf/pages/21165b8b1149400fc1257 21f0051efe4!OpenDocument (last accessed 7/9/2010).

21. UNESCO, Federal Ministry of Education and Research (BMBF) Germany, and German Commission for UNESCO. Proceedings UNESCO World Conference on Education for Sustainable Development, Bonn, Germany, March 31-April 2, 2009. UNESCO, Paris, 2009. http://www.esd-worldconference-2009.org/fileadmin/download/ ESD2009ProceedingsEnglishFINAL.pdf (last accessed 7/9/2010).

22. UNESCO. Framework for the UN DESD International Implementation Scheme ED/ DESD/2006/PI/. Section for Education for Sustainable Development (ED/PEQ/ESD), Division for the Promotion of Quality Education, UNESCO, Paris, 2006. http://www. unesco.org/en/esd/publications/ (last accessed 7/9/2010).

23. Gillett JE. Chemical engineering education in the next century. Chem Eng Technol 2001;24(6):561-570.

24. de Graaff E, Saunders-Smits GN, and Nieweg MR. Research and Practice of Ac- 
tive Learning in Engineering Education. Amsterdam University Press, Amsterdam, Netherlands , 2007.

25. European Union. Recommendation of the European Parliament and the European Council of 18 December 2006 (2006/962/ EC). Official Journal of the European Union L 394/13, 30.12.2006EN. http://eur-lex.europa.eu/LexUriServ/LexUriServ.do?uri=OJ: L:2006:394:0010:0018:en:PDF (last accessed 7/9/2010).

26. Commission of the European Communities. Adult Learning: It Is Never Too Late to Learn. $\operatorname{COM}(2006) 614$ final, Brussels, Belgium, 23.10.2006. http://eur-lex. europa.eu/LexUriServ/site/en/com/2006/ com2006_0614en01.pdf (last accessed 7/9/2010).

27. Blackmore C. What kinds of knowledge, knowing and learning are required for addressing resource dilemmas? A theoretical overview. Environ Sci Policy 2007;10:512525.

28. Keen M, Brown VA, and Dyball R (eds.). Social Learning in Environmental Management: Towards a Sustainable Future. Earthscan, London, 2005.

29. Wals AEJ (ed.). Social Learning Towards a Sustainable World: Principles, Perspectives, and Praxis. Wageningen Academic, Wageningen, Netherlands, 2007.

30. McGregor SLT. Reorienting consumer education using social learning theory: Sustainable development via authentic consumer pedagogy. Int J Consumer Studies 2009;33:258-266.

31. Glasser H. An early look at building a social learning for sustainability community of practice: RCE Grand Rapids' flagship project. J Educ Sustain Dev 2010;4(1):61-72.

32. Lotz-Sisitka $\mathrm{H}$, O'Donoghue $\mathrm{R}$, and Wilmot D. The Makana regional centre of expertise: Experiments in social learning. J Educ Sustain Dev 2010;4(1):73-91.

33. Finger $M$, and Verlaan P. Learning our way out: A conceptual framework for social-environmental learning. World Dev 1995;23:505-513.

34. Daniels S, and Walker G. Collaborative learning: Improving public deliberation in ecosystem-based management. Environ Impact Assess Rev 1996;16:71-102.

35. Woodhill J, and Röling N. The second wing of the eagle: The human dimension in learning our way to more sustainable futures. In Röling NG, and Wagemakers MAE (eds.). Facilitating Sustainable Agriculture: Participatory Learning and Adaptive Management in Times of Environmental Uncertainty. Cambridge University Press, Cam- bridge, England, 1998.

36. Tippett J, Searle B, Pahl-Wostl C, et al. Social learning in public participation in river basin management-Early findings from HarmoniCOP European case studies. Environ Sci Policy 2005;8(3):287-299.

37. Bandura A. Social Learning Theory. Prentice Hall, Englewood, NJ, 1977.

38. Bandura A, and Walters RH. Social Learning and Personality Development. Holt, Rinehart and Winston, New York, 1963.

39. Lipman M. Thinking in Education, 2nd ed. Cambridge University Press, Cambridge, England, 2003.

40. Luksa F, and Siebenhünerb B. Transdisciplinarity for social learning? The contribution of the German socio-ecological research initiative to sustainability governance. Ecol Econ 2007;63:418-426.

41. Board on Sustainable Development of the National Research Council. Our Common Journey: A Transition Toward Sustainability. National Academy Press, Washington, 1999.

42. Parson E, and Clark WC. Sustainable development as social learning: Theoretical perspectives and practical challenges for the design of a research program. In Gunderson L, Holling CS, and Light SS (eds.). Barriers and Bridges to the Renewal of Ecosystems and Institutions. Columbia University Press, New York, 1995.

43. Fadeeva Z, and Mochizuki Y. Lessons learnt in the first half of the UNDESD. J Educ Sustain Dev 2010;4(1):51-59.

44. Morgan AD. Learning communities, cities and regions for sustainable development and global citizenship. Local Environ 2009;14(5):443-459.

45. Wals AEJ, and van der Leij T. Introduction. In Wals AEJ (ed.). Social Learning Towards a Sustainable World. Wageningen Academic, Wageningen, Netherlands, 2007, pp. 17-32.

46. Jucker R. Sustainability? Never heard of it! Some basics we shouldn't ignore when engaging in education for sustainability. Int J Sustain in Higher Educ 2002;3(1):8-18.

47. Steinemann A. Implementing sustainable development through problem-based learning: Pedagogy and practice. J Prof Issues in Eng Educ and Pract 2003;129(4):216-24.

48. Warburton K. Deep learning and education for sustainability. Int J Sustain in Higher Educ 2003;4(1):44-56.

49. Meehan B, and Thomas I. University education for sustainability: Projects, problems, and professionalism. Sustainability: The Journal of Record. 20081(2):124-129. 50. Pike L, Shannon T, Lawrimore K, et al.
Science education and sustainability initiatives: A campus recycling case study shows the importance of opportunity. Int J Sustain in Higher Educ 2003;4(3):218-229.

51. Dohn H, Gausset Q, Mertz O, et al. Strengthening learning processes in natural resource management in developing countries through interdisciplinary and problemoriented learning. Int J Sustain in Higher Educ 2003;4(2):106-125.

52. Ryu HC, Brody SD. Examining the impacts of a graduate course on sustainable development using ecological footprint analysis. Int J Sustain in Higher Educ 2006;7(2):158-175.

53. Hutchings B. Principles of EnquiryBased Learning. Centre for Excellence in Enquiry-Based Learning Resources, University of Manchester, England, 2006.

54. Beringer, J. Application of problem based learning through research investigation. J Geogr in Higher Educ 2007;31(3):445-57.

55. Ellis G, and Weekes T. Making sustainability real: Using group-enquiry to promote education for sustainable development. Environ Educ Res 2008;14(4):482-500.

56. Gabbert B, Johnson DW, and Johnson R. Cooperative learning, group-to-individual transfer, process gain, and the acquisition of cognitive reasoning strategies. J Psychol 1986;120(3):265-78.

57. Coppola BP. Progress in practice: Teaching and learning with case studies. Chem Educator 1996a;1(4):1-13.

58. Coppola BP. Progress in practice: Exploring the cooperative and collaborative dimensions of group learning. Chem Educator 1996b;1(1):1-9.

59. CockrellKS, CaplowJA, andDonaldsonJF. A context for learning: Collaborative groups in the problem-based learning environment. Rev Higher Educ 2000;23(3):347-63. 60 . vonBlottnitz $\mathrm{H}$. Promoting active learning in sustainable development: Experiences from a 4th year chemical engineering course. J Cleaner Produc 2006;14:916- 923.

61. Bremer MH, and López-Franco R. Sustainable development: Ten years of experience at ITESM's graduate level. J Cleaner Produc 2006;14:952-957.

62. Dengler M. Classroom active learning complemented by an online discussion forum to teach sustainability. J Geogr in Higher Educ 2008;32(4):481-494.

63. Clugston R, and Calder W. Food and higher education for sustainable development. J Educ Sustain Dev 2007;1(2):209-218. 64. Dieleman H, and Huisingh D. Games by which to learn and teach about sustainable development: Exploring the relevance of 
games and experiential learning for sustainability. J Cleaner Produc 2006;14:837-847.

65. Domask JJ. Achieving goals in higher education: An experiential approach to sustainability studies. Int J Sustain in Higher Educ 2007;8(1):53-68.

66. Calder W, and Clugston R. Education for a sustainable future. J Geogr in Higher Educ 2005;29(1):7-12.

67. Kolb DA. Experiential Learning: Experience as the Source of Learning and Development. Prentice-Hall, Upper Saddle River, NJ, 1984.

68. Stanley K, and Plaza D. No passport required: An action learning approach to teaching about globalization. Teaching Sociology 2002;30(1):89-99.

69. Dawe G, Jucker R, and Martin S. Sustainable Development in Higher Education: Current Practice and Future DevelopmentA Report for the Higher Education Academy. Higher Education Academy, York, England January 16, 2005.

70. Wals AEJ. The end of ESD... the beginning of transformative learning-Emphasizing the E in ESD. In Kestävääkehitystäedistäväkoulutus -seminaari 15.2.2006 MikkoCantell (toim.) Helsinki: Suomen UNESCO, 2006.toimikunta. http://www. minedu.fi/export/sites/default/OPM/Kansainvaeliset_asiat/kansainvaeliset_jaerjestoet/ unesco/suomen_unesco-toimikunta/ julkaisut/Kestxvx_kehitystx_edistxvx_koulutus.pdf (last accessed 7/9/2010.

71. Wals AEJ, and Blaze Corcoran P. Sustainability as an Outcome of Transformative Learning. Education for Sustainable Development in Action, Technical Paper No. 3. In Holmberg J, and Samuelsson BE (eds.), Drivers and Barriers for Implementing Sustainable Development in Higher Education. UNESCO, Paris, 2006. http://unesdoc. unesco.org/images/0014/001484/148466e. pdf (last accessed 7/9/2010.

72. Bergeå O, Karlsson R, Hedlund-Åström A, et al. Education for sustainability as a transformative learning process: A pedagogical experiment in ecodesign doctoral education. J Cleaner Produc 2006;14:1431-1442. 73. Ilisko D. Teacher as agents of societal change. J Teacher Education for Sustain 2007;7:14-26.

74. Mezirow J. Learning as Transformation: Critical Perspectives on a Theory in Progress. Jossey Bass, San Francisco, 2000.

75. McGregor S. Sustainable consumer empowerment through critical consumer education: A typology of consumer education approaches. Int J Consumer Studies 2005;5:437-447.

76. Global Action Plan. Principles for Empowering Design. Stockholm, 2009. http://issuu.com/xander/docs/emp_design_basic/1?mode=a_p (last accessed 7/09/2010).

77. Global Action Plan. The Wallström Brains Trust: Background Paper to the 6th Environmental Action Program Based on a Discussion on Stakeholder and Citizen Involvement Convened by Margot Walström. Malmö, Sweden, 2001. http://issuu.com/xander/ docs/wallstrom_brainstrust $/ 29$ ? mode $=$ a_p (last accessed 7/09/2010).

78. Staats HP, and Harland P. The Ecoteam Program in the Netherlands: Study 4: A Longitudinal Study on the Effects of the Eco Team Program on Environmental Behavior and Its Psychological Background. Summary Report, 1995. Center for Energy and Environmental Research, Leiden University, Netherlands, E\&M/R-95/57. http://issuu. com/xander/docs/leiden/6? mode=a_p (last accessed 7/09/2010).

79. Wong EOW. Analysing the contribution of continuing education and leadership empowerment to sustainable development: Experiences from a Hong Kong tertiary institution. Int J Sustain in Higher Educ 2003;4(4):364-374

80. Stapp WB. Watershed education for sustainable development. J Sci Educ Technol 2009; 9(3):183-197.

81. Holden M, Elverum D, Nesbit S, et al. Learning teaching in the sustainability classroom. Ecol Econ 2008;64:521-533.

82. Vella, Jane. Learning to Listen, Learning to Teach: The Power of Dialogue in Educating Adults. Jossey-Bass, Hoboken, NJ, 2002.

83. Loeber A, van Mierlo B, Grin J, et al. The practical value of theory: Conceptualising learning in the pursuit of a sustainable development. In Wals AEJ (ed.), Social Learning Towards a Sustainable World. Wageningen Academic, Wageningen, Netherlands, 2007, pp. 83-97.

84. Segalàs J, Ferrer-Balas D, and Mulder KF. What do engineering students learn in sustainability courses? The effect of the pedagogical approach. I Cleaner Produc 2010;18:275-284.

85. Biggs J, and Tang C. Teaching for Quality Learning at University: What the Student Does. McGraw-Hill/Society for Research into Higher Education \& Open University
Press, Maidenhead, England, 2007. 86. Parkin S, Johnston A, Buckland H, et al. Learning and Skills for Sustainable Development: Developing a Sustainability Literate Society. Guidance for higher education institutions. Higher education partnership for sustainability. Forum for the Future, London, 2004.

87. Kendler BS, and Grove PA. Problembased learning in the biology curriculum. Am Biol Teacher 2004;66(5):348-354.

88. Creedy D. Developing PBL facilitation skills: A workshop. In Conference Papers for Problem-Based Learning in Education and Training. University of Sydney, 1992.

89. Dahlgren LO. Problem Based Learning: Experiences from the Health University. Occasional Paper 93.2. Educational Research and Development Unit, RMIT, Melbourne, Australia, 1993.

90. Waldron D, and Leung P. Strategic leadership towards sustainability: A master's program on sustainability. Prog Ind Ecol Int J, 2009;6(3): 307-313.

91. When assessing the impact of different pedagogical approaches and design elements, the survey asked respondents to evaluate the impact based on the following categories: "Detracted from my development," "No impact on my development," "A slightly positive impact on my development," "A very positive impact on my development," "Critical/Essential to my development," "Not applicable in my year" (this was added because there have been minor adjustment in certain elements over the years), and "Not sure."

92. This survey was conducted in August 2010, when there were 306 active alumni.

93. Percentages here indicate the combined results for "Somewhat Enhanced" plus "Greatly Enhanced" divided by the total number of participants who self-assessed as not "Already quite good at this, thus limited room for improvement." All results will be reported in this manner.

94. Given the dates of the survey, 40 of the 142 respondents had graduated less than two months earlier; thus these statistics have limited meaning and application.

Address correspondence to: Tamara Connell, MSLS Blekinge Institute of Technology SE-371-79 Karlskrona, Sweden

Email: tamara@kitesh.org 